\title{
QUEEN'S
QNIVERSITY
BELFAST
}

\section{Paramountcy, family rights and contested adoption: does contact with birth relatives balance the scales?}

MacDonald, M., \& McLoughlin, P. (2016). Paramountcy, family rights and contested adoption: does contact with birth relatives balance the scales? Child Care in Practice, 22(4), 401-407.

https://doi.org/10.1080/13575279.2016.1208147

\section{Published in:}

Child Care in Practice

\section{Document Version:}

Peer reviewed version

Queen's University Belfast - Research Portal:

Link to publication record in Queen's University Belfast Research Portal

\section{Publisher rights}

(c) 2016 The Child Care in Practice Group.

This is an Accepted Manuscript of an article published by Taylor \& Francis in Child Care in Practice on 15 September 2016, available online: http://www.tandfonline.com/10.1080/13575279.2016.1208147.

\section{General rights}

Copyright for the publications made accessible via the Queen's University Belfast Research Portal is retained by the author(s) and / or other copyright owners and it is a condition of accessing these publications that users recognise and abide by the legal requirements associated with these rights.

Take down policy

The Research Portal is Queen's institutional repository that provides access to Queen's research output. Every effort has been made to ensure that content in the Research Portal does not infringe any person's rights, or applicable UK laws. If you discover content in the Research Portal that you believe breaches copyright or violates any law, please contact openaccess@qub.ac.uk. 
Mandi MacDonald, Queen's University Belfast

\section{Priscilla McLoughlin}

June 2016

This paper combines practitioner insight and research evidence to chart how principles of partnership and paramountcy led to birth family contact becoming the expected norm following contested adoption from care in Northern Ireland. It highlights how practice has adapted to the delay in proposed reforms to adoption legislation, resulting in the evolution of increasingly open adoption practices. Adoption represents an irrevocable transfer of parental responsibility from birth to adoptive parents and achieves permanence and legal security for children in care who cannot return to birth family. Its enduring effect, however, makes public adoption a contentious field of child welfare practice, particularly when contested by birth parents. This paper explores how postadoption contact may be viewed as reconciling the uneasy interface between paramountcy principles and parental rights to respect for family life. It highlights the complexity of adoptive kinship relationships following contested adoption from care, and how contact presents unique challenges that mitigate against meaningful and sustainable connections between the child and their birth relatives. In conclusion, a call is made for sensitive negotiation and support of contact arrangements, and the development of practice models that are informed by an understanding of the workings of adoptive kinship.

\section{Introduction}

Since the implementation of the Children (Northern Ireland) Order 1995 Northern Ireland has seen an increased use of adoption to provide continuity, stability and enduring relationships to children in State care who cannot return home to their birth family (Kelly and McSherry, 2002). As is the case across the UK and in the US, many of these adoptions are contested by birth parents and made via legislation, e.g. Freeing Orders in Northern Ireland, which dispenses with the need for parental consent (Tefre, 2015; Kelly and McSherry, 2002). Non-consensual adoption from care, however, is a contested area of child-welfare practice because of its life-long implications for birth parent and child, and the necessity and proportionality of the rights infringements it entails are strongly debated (Bywaters, 2015).

A foundational principle of the Children Order is that the welfare of the child shall be the court's paramount consideration in any question regarding their upbringing (Art. 3). Concomitant with this paramountcy principle is an imperative to ensure that children have a secure, stable and loving family to support them through childhood and beyond' (DfE, 2015b, p.6), placing an emphasis on permanence planning for all children involved in child welfare services. While adoption delivers good 
outcomes for children in care, upholding the paramountcy of their welfare, it does not sit easily with the principles of partnership and family preservation which are equally foundational to the Children Order.

This paper examines how practice in Northern Ireland has adapted to the delay in proposed reforms intended to align adoption legislation more closely to the principles of the Children Order. In particular, it charts how partnership working and efforts to prevent family separation have led to increasingly open practices whereby most adopted children in Northern Ireland will now have some form of contact with birth relatives after adoption. The paper questions whether post-adoption contact does indeed, as it is sometimes viewed as doing, reconcile the uneasy interface between paramountcy principles and parental rights to respect for family life.

This discussion is informed by systematic narrative reviews of policy and research in relation to postadoption contact undertaken as part of two research projects exploring the separate perspectives of adoptive parents (MacDonald, 2015; 2016) and birth parents (McLoughlin, 2013). It also draws on the practice experience of both authors who have worked as social workers in the field of adoption and permanence planning for looked after children.

\section{Adoption as a permanence option for Looked After children}

The Children Order reflects important guiding principles of the UNCRC which specifies that children have a right to be cared for by their parents unless this would be significantly harmful to them (Article 7), in which case they have a right to benefit from continuity of alternative care (Article 20), and to know their parents even if living separately from them (Article 7). These principles are enacted in child welfare policy, the primary focus of which is on enabling children to be cared for by their birth families, with services targeted at family preservation to prevent children coming into care, and to facilitate re-unification when they do. This is echoed in the rhetoric of care planning and permanence which presents a hierarchy of placement options that prefers children to grow up with their birth parents when possible, or with extended kin as the next best choice.

When family preservation is not achievable, however, a core objective of child welfare policy, reflecting the imperative of paramountcy, is to provide alternative family placements that are permanent and secure. In recent years adoption has been increasingly utilised, particularly in the UK and US, to achieve permanence for children in state care who cannot safely return home to their birth parents or other birth kin (Tefre, 2015; Kelly and McSherry, 2002). Across the UK 6,124 children were adopted from care in 2014, representing approximately $7 \%$ of all children in state care that year (DfE, 2015a; The Scottish Government, 2015; The Welsh Government, 2015). Of these children 
adopted from care, 72 were in Northern Ireland representing 9\% of discharges from care here in 2014/15 (DHSSPS, 2015). For many such children, adoption offers the best route to a secure family upbringing and lifelong relationships (DfE, 2015b), improving their life chances, providing stability, upholding their UNCRC right to continuity of care, and facilitating recovery from adversity (Selwyn et al, 2015).

The adoption of children in State care who cannot return to their family of birth requires assessment, care planning and legal intervention by public child welfare agencies who undertake to place the child permanently with non-kin. This public form of adoption, especially when contested by birth parents, involves a particularly intrusive role for the State in regulating the breaking and making of legal family ties. Under the Care Order or Residence Order provisions of the Children Order, parental responsibility only ever becomes shared not extinguished. In contrast to this, an Adoption Order effects a total and permanent transfer of legal parenthood from birth to adoptive parents, who exclusively and irrevocably assume the parental rights and responsibilities relinquished by, or removed from, the birth parents.

Adoption also highlights questions about the extent to which child safety should be prioritised over family preservation. When children cannot safely live with birth relatives, there is an inherent tension in the State's duty to protect, but to do so in a way consistent with the right to respect for family life. However, only a minority of children are adopted from care with the consent of their birth parents. The majority of public adoptions in Northern Ireland, for example, are contested, and achieved via Freeing Orders applications under The Adoption (Northern Ireland) Order 1987 (NIGALA, 2015). Dispensing with parental consent to adoption in this way is justified in law on the basis of safeguarding the child's welfare, but does not sit easily with human rights or the children's rights principles that are foundational to the Children Order.

Particularly contentious in the UK have been recent policy moves toward increasing the rate and speed of adoptions from care in order to safeguard children from maltreatment, and avoid care planning drift. This drive has been a response, in part, to critiques that the child welfare system, skewed by romanticised notions about birth ties (Tefre, 2015), prioritises the interests of parents over the needs of children, with prolonged efforts at rehabilitation exceeding the timeframes that are in a child's best interest (Brown and Ward, 2013). However, critics have counter-argued that policy drives for adoption result in adults' needs being too readily overlooked (Bywaters, 2015). The polarities in this debate reflect the juxtaposition of parent and child rights at the centre of contested adoption from care.

\section{Children Order principles and the development of open adoption}


The strong explicit policy and legislative emphasis on keeping children with their birth families means that many children who are eventually adopted will have lived with their birth parents prior to their admission to care, and, once in foster care, extensive efforts will be made toward reunification, before a care plan of adoption is agreed. The provisions of the Children Order, furthermore, recognised children's right under the UNCRC (Article 9) to stay in contact with both parents, unless this might hurt them, and introduced a presumption of contact for children throughout their time in care. These frameworks comprise a mandate to ensure that children have contact with significant birth relatives while they are in care, and are allowed continued connection with their birth parents following adoption.

Because of the high stakes resting on decision-making, contested adoptions require an intensive process of multi-disciplinary assessment, consultation, and debate, and legal proceedings are necessarily rigorous and often lengthy. As a result, many children may spend months or years in the care of temporary foster carers before being adopted. Most adoptions from care are finalised between the child's first and fifth birthdays (DfE, 2015a; DHSSPS, 2015).

While much of this delay purposefully explores and exhausts options for family preservation, protracted care planning processes come under criticism for falling short of upholding the child's welfare as the paramount concern. Research consistently suggests that the earlier children are placed in their permanent placement, the more likely that placement is to succeed (Rushton, 2007; Biehal et al, 2010; Selwyn et al, 2015).

Distinctively in Northern Ireland child placement practice has evolved to ameliorate this tension by approving prospective adopters also as foster carers. In 2014/15, 66\% of new adopters in the region were approved also as foster carers (HSCB, 2015). Referred to locally as "dual approval" this process has more recently been introduced in England and Wales under the term "foster to adopt". It enables children to be placed with their prospective adoptive parents on a fostering basis at an earlier stage, when a plan of adoption has been agreed by the Health and Social Care Trust which is the public child welfare agency with statutory responsibility for care planning. This practice maximises opportunities for children's early attachment to their permanent care givers, removing the necessity of care moves and consequently reducing the potential for attachment disruption. Simultaneously, and if it is assessed as being in their interests, the children may continue to have high levels of parental contact which carers are often involved in facilitating (Kelly et al, 2007; Simmonds, 2013). 
Therefore, consequent to the principles of partnership and prevention, many children adopted from care arrive in their adoptive placement with some existing relationships with birth relatives. Contact after adoption can provide continuity in birth relationships, and facilitating ongoing connection with birth relatives, in some form, is considered humane and potentially beneficial to the child as long as this does not undermine the prospect of a stable adoption (Neil et al, 2011). Contact after adoption may be indirect, via written communication, or direct and involving face-to-face meetings between the child and any combination of birth relatives, with or without the facilitation of an adoption agency intermediary.

There is some evidence of a strong presumption of contact in Northern Ireland and higher rates of direct face-to-face contact compared with the rest of the UK. In England and Wales, for example, it is estimated that a significant minority (Neil et al, 2011), perhaps as few as one in five (Jones, 2016) children adopted from public care are likely to have direct contact with a birth relative. However, in Kelly's (2012) survey of 89 adopters in Northern Ireland the majority (89\%) of domestic adopters reported some form of post-adoption contact, with a trend towards higher rates of contact generally, and direct contact in particular, in more recent adoptions. This trend towards increased rates of post-adoption contact, with more children having face-to-face meetings with birth relatives, is reflected in anecdotal accounts of practitioners in this region.

Proposed contact arrangements are thoroughly considered during adoption proceedings to ensure that agreements are in place to facilitate children's ongoing birth connections. There is currently, however, no formal mechanism for recording the numbers of families having post-adoption contact or the form these arrangements take, nor is there any statutory reporting of social work involvement in contact arrangements after adoption. Therefore, it is not clear how many adoptive families in Northern Ireland have contact with birth relatives, what form this contact takes, how often, and with which birth relatives. Judicial scrutiny of contact arrangements reveals the somewhat ambiguous position of adoptive parents who have a right to respect for the family life that is created, in a legal sense, by the making of an Adoption Order, but who have reported feeling constrained to comply with contact plans as a non-negotiable condition of adoption (MacDonald, 2016). However, there is limited information on how adoptive families experience and manage contact arrangements or what resources they draw on for support if difficulties arise.

\section{The complexities of post-adoption contact}

While post-adoption contact is often seen as consistent with both the child and birth parent's right to family life, it brings its own potential difficulties and added complexity to adoptive family life. From the perspective of child welfare, research evidence would suggest that neither contact nor lack 
of it necessarily leads to psychosocial difficulties (Quinton and Selwyn, 2006; Jones, 2016). However, while contact can bring benefits to children, birth parents and adoptive families (Neil et al, 2011) it can also present a range of difficult issues, cause children to be unsettled and anxious, and prove stressful for all involved. In their study of 'complex' contact arrangements following adoptions from care, Neil et al (2011) found that over half of the children were having direct contact with a birth relative that had previously neglected or abused them. The adoptive parents reported challenges in these situations that centred on the child's negative reaction to contact, the quality of interactions during meetings, and managing risks and boundaries. For all involved, contact can involve intense emotions, described by birth parents as an emotional roller coaster with each contact visit welcomed but culminating in repeated experiences of loss (McLoughlin, 2013).

Many birth parents who lose a child to compulsory adoption struggle with the enduring negative impact of the adoption (Neil et al, 2011) and the ongoing significant social, psychological or health difficulties that precipitated it. Many birth parents struggle to accept the decisions of social services and the Court, and continue to feel a strong sense of injustice years after the adoption, sometimes failing to grasp the legal permanence of the arrangement (McLoughlin, 2013). Roles and relationships in the adoptive kinship network can be particularly ambiguous and potentially conflicted when the adoption is contested. Whilst many birth parents value the opportunity for faceto-face contact with their child, and appreciate the care provided by their adoptive parents (Neil et al, 2011; McLoughlin, 2013), some can be reluctant to acknowledge the parental status of adopters (MacDonald, 2015), or find it difficult to manage the changed dynamics brought about by adoption (McLoughlin, 2013). Some adopters have recounted engaging in social avoidance to guard the physical boundary of their family in response to perceived or verbalised risk of aggression by birth relatives or suggestions that they would attempt to reclaim the child (MacDonald, 2016).

Relationships in the adoptive kinship network, particularly following contested adoption, are, therefore, exceptionally complex. The current vocabulary of kinship is inadequate to describe relational roles and expectations between birth and adoptive families, (MacDonald, 2015), and in the absence of a social template to guide interactions (Grotevant, 2000) open adoption requires all parties to forge new ways of doing family relationships (Jones, 2016). Professionals, and indeed parents, who are at the centre of this complex field of practice are hungry for information that would help them determine what contact arrangements might be right for any particular child, and how relationships might best be supported.

\section{Conclusion}


1 Adoption from care sits at the axis of the intersecting, and sometimes opposing, rights claims of

2 parent and child, with the child's right to safety and permanence held in tension with the importance of preserving birth relationships and a mandate to respect private and family life (Tefre, 2015; MacDonald, 2016). In an effort to resolve this tension, adoption has become increasingly open, to the extent that post-adoption contact now proliferates. The principles of partnership and prevention that are foundational to the Children Order established a policy environment in which adoption practice has been able to evolve to take account of the needs and rights of the various parties. However, birth relative contact continues to generate professional disquiet emphasising the paradoxical nature of installing the child in a permanent new family while retaining the significance of their original family (Sales, 2012), and highlighting the difficulty of upholding the child's right to this dual connection in a way that does not compromise their wellbeing.

Given the significant complexities of contact for all parties, it is questionable whether arrangements do indeed offer children beneficial and enduring relationships with birth relatives. In order for postadoption contact to be sustainable over time and provide children with meaningful birth connections, there is professional imperative to develop practice that is: sensitive to the child's needs and not cause undue distress; facilitates comfortable interaction between the connected but separate individuals in the adoptive kinship network; empowering and enabling and avoids the imposition of formulaic or restrictive arrangements; that is sensitive to the needs and feelings of all parties (Neil et al, 2011; Siegel and Smith, 2012). This will require more sophisticated ways of scaffolding these pioneering relationships (Grotevant, 2000), and the development of practice models that are sensitive to the workings of kinship and the particular complexities of forging and maintaining a sense of kin connection between adoptive and birth families.

\section{References}

BIEHAL, N., ELLISON, S., BAKER, C. AND SINCLAIR, I. (2010) Belonging and Permanence: Outcomes in long-term foster care and adoption England: Adoption Research Initiative Research Report, London: BAAF

BROWN, R. and WARD, H. (2013) Decision-making Within a Child's Timeframe. Loughborough: Childhood Wellbeing Research Centre, Working Paper 16.

BYWATERS, P., (2015). Cumulative jeopardy? A response to Brown and Ward. Children and Youth Services Review, 52, pp. 68-73.

DEPARTMENT FOR EDUCATION (DFE) (2015a) Children looked after in England (including adoption and care leavers) year ending 31 March 2014, London: DfE

DEPARTMENT FOR EDUCATION (DfE)(2015b). Permanence, long term foster placements and ceasing 
to look after a child: Statutory guidance for local authorities. London: DfE.

Department of Health Social Services and Public Safety (DHSSPS) (2015) Children's Social Care Statistics for Northern Ireland 2014/15, Belfast: DHSSPS

GROTEVANT, H.D., (2000). Openness in adoption: Research with the adoption kinship network. Adoption Quarterly, 4(1), pp. 45-65.

HEALTH AND SOCIAL CARE BOARD (HSCB) (2015), ARIS Annual Report 2014/15, Belfast: HSCB

JONES, C. (2016) Openness in adoption: Challenging the narrative of historical progress. Child and Family Social Work, 21(1), pp.85-93.

KELLY, G. and MCSHERRY, D., 2002. Adoption from care in Northern Ireland: problems in the process. Child \& Family Social Work, 7(4), pp. 297-309.

KELLY, G., HASLETT, P., O'HARE, J. AND MCDOWELL, K. (2007), Permanence planning in Northern Ireland: A development project, Adoption \& Fostering, 31(3), pp. 18-27.

KELLY, G. (2012). Listen up - Speak Out: A Survey of Adoptive Parents in Northern Ireland. Belfast: Adoption UK.

MACDONALD, M., (2015). A picture of who we are as a family': conceptualizing post-adoption contact as practices of family display. Child and Family Social Work. DOI: 10.1111/cfs.12248

MACDONALD, M., (2016 in press). Parenthood and Open Adoption: an Interpretative Phenomenological Analysis, Basingstoke: Palgrave Macmillan.

MCLOUGHLIN, P., (2013). Does Seeing Their Children After Adoption Help Non-Consenting Birth Parents In Accepting And Supporting The Adoption Placement?, University of Ulster: Unpublished Master's Thesis

NEIL, E., COSSAR, J., JONES, C., LORGELLY P., AND YOUNG J. (2011) Supporting Direct Contact After Adoption. London; BAAF

NIGALA (2015), Northern Ireland Guardian ad Litem Agency (NIGALA) Annual Report 2014/15, Belfast: NIGALA

QUINTON, D. and SELWYN, J., (2006) Adoption: Research, Policy and Practice. Child and Family Law Quarterly, 18(4), p459-477.

RUSHTON, A. (2007), Outcomes of adoption from public care: research and practice issues, Advances in Psychiatric Treatment (2007), 13, pp. 305-311 
1 SALES, S., (2012). Adoption, Family and the Paradox of Origins: A Foucauldian History. London:

2 Palgrave Macmillan

3 SELWYN, J. MEAKINGS, S. \& WIJEDASA, D. (2015) Beyond the Adoption Order: Challenges,

4 Interventions and Adoption Disruption. London: BAAF.

5 SIEGEL, D.H. and SMITH, S.L., (2012), Openness in Adoption: from Secrecy and Stigma to Knowledge

6 and Connections. New York: Evan B. Donaldson Institute.

7 SIMMONDS, J. (2013), Fostering for Adoption: Becoming a Carer, London: Coram and BAAF

8 TEFRE, $\varnothing$.S. (2015). The justifications for terminating parental rights and adoption in the United

9 States. Children and Youth Services Review, 48, pp. 87 - 97

10 THE SCOTTISH GOVERNMENT (2015) Children's Social Work Statistics 2014, Scotland: The Scottish

11 Government

THE WELSH GOVERNMENT (2015) Children's Services Statistics Wales, Wales: The Welsh Government 